\title{
The Development Trends of Management of the Institutions of Vocational Music Education in Latvia
}

\author{
Vita Stige-Skuskovnika Mg. sc. soc. \\ Turiba University, Latvia \\ vita.stige@gmail.com
}

\begin{abstract}
Music education system in Latvia consists of state, municipal and private education institutions that provide vocation-oriented, vocational secondary and higher education programs. Industrial and field policy is prepared by the Ministry of Culture, its' implementation is coordinated and managed by the Latvian National Cultural Centre. But the leadership and development of institutions of the vocational music education in Latvia is a responsibility of the music school leaders. The main object for the research is the development trends of management of the institutions of vocational music education. The aim of the article is to study and analyse the development trends of management of the institutions of vocational music education in Latvia in last five years and in current situation. Using analysis of scientific literature, statistics and normative documents, as well as interviews, in this article authors gives an overview of the main development trends of vocational music education system in Latvia and analyses interview results pointing out the advantages of the management strategies and problems in the institutions of vocational music education in Latvia.
\end{abstract}

Keywords: vocational music education, management, school leadership, leader.

\section{Introduction}

In this paper authors continue their previous research by analysing the development trends of management of the institutions of vocational music education in Latvia which are important in the context of education system as whole. The emphasis on music schools was chosen, giving a focus on the main aspects of development trends of management of previously mentioned institutions.

In addition, in previous literature research authors of the paper have analysed two core concepts educational management and school leadership more detailed giving an insight into the range of definitions and approaches by different authors (Bush, 2007, 2008; Sun, 2014; Black, 2007; Hallinger, Chen, 2015; Steward, 2014; Northfield, 2014; Spillane, Halverson, Diamond, 2004; Jamali, 2005). In summary one of the main conclusions is that effective leadership and management are increasingly regarded as essential if music schools are to achieve the wide-ranging objectives set for them by their many stakeholders (Stige-Skuskovnika, Davidova, 2015).

The goal of vocational education is to provide opportunities for further education after the elementary or secondary school, to acquire initial vocational qualifications, develop skills for continuing vocational education, and acquire the right to continue education at a higher education level. Vocational institutions in Latvia offer educational programs in all sectors of economy.

Cultural education system in Latvia consists of state, municipal and private education institutions that provide vocation-oriented, vocational secondary and higher education programs. They provide training of professional artists, musicians, dancers, cultural and pedagogical professionals (Latvijas nacionalais kulturas..., 2017). Industrial and field policy is prepared by the Ministry of Culture, its' implementation is coordinated and managed by the Latvian National Cultural Centre.

The leadership and development of institutions of the vocational music education in Latvia is a responsibility of the music school leaders whose job has been transformed by extraordinary economic, demographic, technological and global change. This aspect points to an important role of the management skills and knowledge that has become very important for school leaders.

Unfortunately, school leaders mostly are educated in music, performing arts, pedagogy but very rarely they have specific knowledge or/and education in management and leadership despite of its impact on the development of all school processes and pedagogical environment.

The latest review of the Organisation for Economic Cooperation and Development (OECD) states a school leader as a key person in any school. In both general education and vocational schools, school leaders are supported by deputy school leaders. School leaders are usually teachers who were promoted to (deputy) 
principals upon passing a local competition (OECD, 2016). Here authors see the connection with L. Lashway's (Lashway, 2003) point of view that leaders must define themselves as learners, not just doers, constantly scanning the environment for new ideas, tools, and solutions, and reflecting on the implications.

In the context of music school leadership authors studied leader's concept as well. School leaders are those persons, occupying various roles in the school, who provide direction and exert influence in order to achieve the school's goals. Leadership functions can be carried out in many different ways, depending on the individual leader, the context, and the nature of the goals being pursued (Leithwood, Riehl, 2003).

As the title of the study indicates, attention is given to the development trends of management of the institutions of vocational music education in Latvia. This view, by definition, involves changing the major source of inspiration for educational leadership away from management and towards education and learning.

Until now the authors of this paper have given a first insight in school management direction and situation analysis of the field of vocational music education in Latvia. No similar research was carried out thereby giving an invaluable contribution for the general characteristics of the vocational music education field at all giving a helpful background for the further development activities made by to the Latvian National Cultural Centre. In this article authors shows interview results and gives the advantages of the management strategies and problems in the institutions of vocational music education in Latvia.

The aim of the study is to study and analyse the development trends of management of the institutions of vocational music education in Latvia in last five years and in current situation.

\section{Methodology}

The research presented in the paper is part of a larger project analysing the topicalities of management in the institutions of vocational music education in Latvia. In this study the key task is to analyse interview results and understand the current situation of the management strategies and problems in previously mentioned educational institutions.

Till now authors have conducted three semi-structured interviews with eight open questions. According to H.R. Bernard (2006) semi-structured interviewing works very well in projects where you are dealing with high-level bureaucrats and elite members of a community. This type of interviewing is based on the use of an interview guide. This is a written list of questions and topics that need to be covered in a particular order.

The three representatives from public administration where selected on purpose: one informant represents the Ministry of Culture of the Republic of Latvia, two informants - the Latvian National Culture Centre. These informants were selected because of their strong link with music schools which are in subordination of these institutions as it was explained in previous pages of this paper. Also, informants are in direct communication with the principals of these music schools but on their request, authors will keep their anonymity and confidentiality.

Interviews were organized separately with each person "face-to-face", took place at informants' office. Each interview lasted 1-2 hours and was recorded: questions with the aid of a topic list where asked, and possibly additional questions at the end of the interview where posed. Afterwards each interview was transcribed in full to create a written protocol.

Informants were asked about their opinion of current performance of the institutions of vocational music education, tasks given to principals and other aspects of leadership in eight questions. Questions mainly focused on principal's personality as a leader - necessary competences, criteria of evaluation and professional development possibilities. One of the important questions to informants was about future improvement options in the leadership of institutions of vocational music education.

\section{Results and Discussions}

The analysis of results is given sequentially question by question comparing answers by all informants. For this paper authors have chosen to include the most significant points of view to provide the insight into the current situation to the reader.

The first question given by authors was directed to the informants individually to find out their opinion of current activities of the institutions of vocational music education, 
Informant no.1: Current professional cultural education in Latvia consists of three-grade system and provides succession of educational content - sequential shift into the next level of education, as well as gives a chance to young Latvian talents both to prove themselves to the world and successfully develop a high level of professionalism of Latvian professional labour market (Kremerata Baltica, Latvian Radio Choir, the Latvian National Opera and Ballet), which is competitive also in a global level.

Informant no.2: There is no common trend in music schools of Latvia, because of three different aspects. First aspect is that schools in Riga are working with professional orientation and higher quality to obtain the objective to target children at least try to enter secondary music schools and become professional musicians. Second aspect is regional schools of Riga where the population is growing steadily, and we face the situation that all the time additional school places are needed because the school is the only place where to stay. Third aspect is the rest of the music schools of Latvia. The further away from Riga, the greater part of it takes a social function. Rural schools are trying to attract children to music schools, so they can get a good cultural education and be able to have a chance to get away from that social environment in which they live. So, because of these aspects it's very difficult to find one trend that could characterize all music schools of Latvia.

Informant no.3: Music schools are more than the post offices - post offices are closing, but music school are opening. Each school has its own story and contingent of students that comes to the school. If, for example, in Latgale region there are few students, then students in Riga are so much that it's not possible to admit all of them because of the lack of teachers or overload of the existing. There are schools with its own history and union where historically has developed a focus on a particular specialization (for example, Limbaži music school has focused on accordion specialization). In one city music school fulfils school and education function, in another - cultural institutions' function. Authors conclude that vocational education of music in Latvia is in the high level of professionalism and gives great musicians to the world. But also, all informants emphasize one important trend - each music school chooses which function (educational or social) to realize and mostly it depends on geographical location of the music school, number of pupils and social environment.

In the second question authors asked informants if music school principals have to carry out specific tasks for the development of the institutions of vocational music education given by their represented institutions of supervision. All informants denied this statement and stressed that music schools have their freedom in decision making - how to achieve the quality and realize all programs in the frames of school accreditation. Of course, there are some principals who would like to have concrete tasks as it was more than 25 years ago, but informants are sure that current approach gives more free space for creation of individual ideas and self-motivation.

The next two questions focused on music school principals and asked to what extent the activities of the institutions of vocational music education depends on its' principal and what are the most important competences of principals for the effective leadership.

Informant no.1: In my opinion, activities of the music school and, in particular, its' development is highly dependent on its' leader - principal. The importance is in the management of work processes, communication with staff, Latvian National Cultural centre, local authorities and representatives of the government, pupils and their parents. Very often principal of the school is a "business card" and gives the impression to the others. Very important is principal's vision of the schools' development, sense of mission, strategic and administrative thinking, ability to promote new ideas, inspiring and persuading his/her employees, pupils and others.

Informant no.2: The principal is responsible for everything including all classical management functions. The principal is the head of the school, the most important person. Actually, everything depends on him. Here it's important to understand that the principal is not the first of the teachers and that the director is not the failed musician. The principal is the leader of the school. He has to understand the process of documentation because at the moment there is a situation that the various documents are so many that principal must be able to orientate and understand what is specifically needed for his/her school and in what way which document protects him/her. Especially in Riga and Riga region pupils have very welleducated parents who come to the principal with different kind of activities and complaints. The principal shall be a true leader. If he/her comes from the music industry it's a bonus because then he/her has a better understand with the teachers and pupils, and in the same time he/her can be a good example for pupils. 
Informant no.3: Primarily the principal has to know principles of music schools as entities. The second factor in all educational institutions is money. The principal must be able to attract money in order for the school to work. And then there is a need to understand what to do with the money, where to invest, rather than just earn it. As is known, it is difficult to earn much money in the field of art, especially knowing the salary of school heads. The school leader must be a personality that wants to do or prove something through the work in music school rather than just earn the living. Because the responsibilities of music school principals are much higher than monetary gain.

Informant no.1: In my opinion, important is the ability of communication, knowledge of present situation in musical world and also understanding of historical values. Also important is knowledge of administrative work and application of legislative acts relevant to school life. I see that principal of school needs to know how to lead a team and represent the school with honour.

To the first part of question all informants stress the importance of principal as a leader. Leader who has knowledge of management principals and who is a strong personality with high moral standards and vision of school development and future. The second part of this question shows the competencies which was highlighted by informants. Dominant of them are ability to communicate with different groups of people and institutions, strategic and administrative thinking and ability to attract the money. Especially the last competence is one of the core abilities for the school development and growth, according to the authors, because of the financial situation and subsidization of music schools in Latvia last years.

In the next few questions authors have chosen to find out following aspects for the principals of the institutions of vocational music education - dominant criteria for the election, evaluation criteria and evaluation system, professional development possibilities and courses.

All informants confirmed that there are just standard criteria for the election of new principal. These criteria are defined in the Regulations of the Cabinet of the Ministers and they include such aspects as 1) bachelor's or master's degree in education or pedagogy, 2) at least three year work experience in the institution of cultural education, 3) at least three year administrative work experience in leading position in the institution of education or culture, 4) excellent skills of Latvian language (minimum level C1) and at least two foreign languages (minimum level B1), 5) experience in project management and others. Only informant no.3 added that principals are selected by municipalities and institutions in supervision of music schools (such as Latvian National Cultural Centre) have no rights to interfere in decision making. So, it means that principals are recruited by municipalities.

Concerning evaluation criteria and evaluation system of music school principals all informants agreed that there is no system which evaluates principals and that all of them have non-terminated contract. At the moment the reference point is the accreditation and self-assessment report annually. Just informant no.2 notes that State Education Quality Service is considering evaluation system, but this is a very contradictory question because it would require additional capacity to cover all institutions of general education and vocational education (more than 500). Professional development courses for principals are organized six times in the study year by Latvian National Cultural Centre. According to interests of principals the courses and seminars are connecting with such topics as educational leadership, documentation and regulations, rights of children, communication and others.

Informant no.3 added that there are some school principals who attend all the courses, finding a professional fulfilment this way. And later it shows in school performance. These principals are very active - involve their pupils in different activities, take them to competitions and act as performing musicians themselves.

The last question of the interviews was about future improvement options in the leadership of institutions of vocational music education where informants where asked for their personal vision.

Informant no.1: The school principals have to improve their knowledge in the management of creative industries. They must communicate more with partners, competitors, current and future benefactors. They must cooperate with state concert organizations and Jāzeps Vìtols Latvian Academy of Music. They must look for partners abroad. Also, they need to improve the knowledge of marketing and activities in this direction.

Informant no.2: I would like that music schools would not only prepare pupils for future professional work but would give a contribution to the development of daily music culture. One of the goals of music 
schools is to prepare a knowledgeable audience. I think that this preparation is not broad enough. One side is that there are people who love to attend concerts, exhibitions and know how to evaluate what they see. Other side is that there are only few people left that use their musical skills in everyday life by, for example, doing music in their interest groups or families.

One more thing what the school principal must do is to make a good team of program directors. And principal must support this team, so that it can work and cultivate school's prosperity. This direction has lots of space for development.

Informant no.3: Nobody has been taught professionally to be a principal of the school. That's why there could be a "school of principals" where topics important to principal work are discussed. One direction of these topics - documentation and formalities, second - creative work and marketing, public relations. Also, in my opinion, school principals must learn to work more closely with teachers that can give important insights for the school development.

Having processed the results of informants' interviews, authors provided some standpoints characterizing their stance in Table 1.

Main statements from informants' interviews

Table 1

\begin{tabular}{|c|c|}
\hline Informant & Statements from informants' interviews \\
\hline $\begin{array}{l}\text { Informant } \\
\text { no.1 }\end{array}$ & $\begin{array}{l}\text { - Current professional cultural education in Latvia is competitive in a global level } \\
\text { - Music schools have their freedom in decision making } \\
\text { - Activities of the music school and its' development is highly dependent on its' leader } \\
\text { - principal } \\
\text { - The school principals have to improve their knowledge in the management of } \\
\text { creative industries and marketing }\end{array}$ \\
\hline $\begin{array}{l}\text { Informant } \\
\text { no. } 2\end{array}$ & $\begin{array}{l}\text { - There is no common trend in music schools of Latvia, because of three different } \\
\text { aspects } \\
\text { - Music schools have their freedom in decision making } \\
\text { - Everything depends on principal, he shall be a true leader } \\
\text { - The school principal must make a good team of program directors and support this } \\
\text { team for the school development }\end{array}$ \\
\hline $\begin{array}{l}\text { Informant } \\
\text { no. } 3\end{array}$ & $\begin{array}{l}\text { - In one city music school fulfils school and education function, in another - cultural } \\
\text { institutions' function } \\
\text { - Music schools have their freedom in decision making } \\
\text { - The school leader must be a personality that wants to do or prove something through } \\
\text { the work in music school } \\
\text { - The school principal must learn to work more closely with teachers that can give } \\
\text { important insights for the school development }\end{array}$ \\
\hline
\end{tabular}

The answers to interview questions emphasizes four main trends, in opinion of the authors:

- knowledge improvement (creative industries and management, documentation, marketing and public relations);

- cooperation with teachers, program directors and institutions of the musical field;

- musical education not only as a future profession, but just as important - musical skills and inspiration for music making in everyday life;

- the school development depends on its' principal who has to be a true leader.

\section{Conclusions}

Authors conclude that effective leadership and management are increasingly regarded as essential if music schools are to achieve the wide-ranging objectives set for them by their many stakeholders, notably the governments which provide most of the funding for public educational institutions. A number of the factors that are essential to the effectiveness and performance of music schools are under the control of principals. 
As stated in Latvian regulations recruitment of school principals depends highly on their teaching qualifications and experience. There are just standard regulations of the Cabinet of Ministers on school principal recruitment. Music school principals are recruited with non-terminated contract by municipalities of Latvia which means that the Latvian National Cultural Centre has no possibilities to interfere in decision-making.

Analysing results of the research we formulated the following conclusions.

1. There is no common tendency for all institutions of vocational music education in Latvia because capital city and other big cities concentrate on professional level and quality, but regional music schools mostly realize social function for children and their everyday life. Music schools should prepare students not only for future professional career but also give a contribution to the improvement of everyday musical culture.

2. More than 25 years music schools did not have strategic tasks from their institutions of supervision: it gives freedom in decision-making process and deepens self-motivation to achieve individual ideas.

3. Principals have to be able to lead team work, represent his/her school and communicate appropriately, to have knowledge in organisation of administrative work process, which based on music and human values.

4. For improving the competence of music school principals in Latvia is necessary to create system of principals' professional development.

\section{Bibliography}

1. Bernard H.R. (2006). Research methods in anthropology: qualitative and quantitative approaches. ( $4^{\text {th }}$ ed.). Oxford: AltaMira Press.

2. Black R. (2007). Crossing the Bridge: Overcoming entrenched disadvantage through student-centred learning. Melbourne: Education Foundation Australia. Retrieved from https://files.eric.ed.gov/fulltext/ED501899.pdf

3. Bush T. (2007). Educational leadership and management: Theory, policy, and practice. South African Journal of Education, 27(3), 391-406. Retrieved from http://citeseerx.ist.psu.edu/viewdoc/download?doi=10.1.1.729.7350\&rep=rep1\&type=pdf

4. Bush T. (2008). Leadership and Management Development in Education. London: SAGE Publications Ltd. Retrieved from http://www.dphu.org/uploads/attachements/books/books_5057_0.pdf

5. Hallinger P., Chen J. (2015). Review of research on educational leadership and management in Asia: A comparative analysis of research topics and methods, 1995-2012. Journal of Educational Management Administration and Leadership, 43(1), 5-27.

6. Jamali D. (2005). Changing management paradigms: Implications for educational institutions. Journal of Management Development, 24(2), 104-115.

7. Lashway L. (2003). Role of the School Leader: Trends and Issues. Washington, DC: ERIC Clearinghouse on Educational Management.

8. Latvijas Nacionalais Kulturas centrs (Latvian National Cultural Centre). (2017). Kultūrizglìtība (Education of Culture). Retrieved from http://www.lnkc.gov.lv/nozares/kulturizglitiba/ (in Latvian)

9. Leithwood K.A., Riehl C. (2003). What we know about successful school leadership. Philadelphia, PA: Laboratory for Student Success, Temple University.

10. Northfield Sh. (2014). Multi-Dimensional Trust: How beginning principals build trust with their staff during leader succession. International Journal of Leadership in Education: Theory and Practice, 17(4), 410-441.

11. OECD. (2016). Reviews of National Policies for Education. Education in Latvia. Paris: OECD Publishing. Retrieved from http://dx.doi.org/10.1787/19900198

12. Spillane J.P., Halverson R., Diamond J.B. (2004). Towards a theory of leadership practice: a distributed perspective. Journal of Curriculum Studies, 36(1), 3-34. Retrieved from http://ddis.wceruw.org/docs/SpillaneHalversonDiamond2004JCS.pdf

13. Steward J. (2014). Sustaining emotional resilience for school leadership. Journal of School Leadership and Management: Formerly School Organisation, 34(1), 52-68.

14. Stige-Skuskovnika V., Davidova J. (2015). Cooperation-oriented director's competence for development of institutions of vocational music education. Proceedings of the International Scientific Conference, Social Sciences, 57. Daugavpils, Latvia: Daugavpils University, 84-92.

15. Sun R. (2014). Principal's leadership, school management, and student learning outcomes: a study of New York city public schools. PhD Thesis. USA: The State University of New Jersey. 